\title{
PERAN SENTRA BATIK KAUMAN DAN PESINDON UNTUK MENCAPAI KOTA PEKALONGAN SEBAGAI KOTA KREATIF KERAJINAN
}

\author{
Rifdahastuti Andriani ${ }^{1}$, Winny Astuti ${ }^{1}$, Rufia Andisetyana Putri ${ }^{1}$ \\ ${ }^{1}$ Program Studi Perencanaan Wilayah dan Kota, Fakultas Teknik, Universitas Sebelas Maret
}

\begin{abstract}
Abstrak
Kota Pekalongan merupakan kota kreatif pertama kategori kerajinan dan kesenian rakyat di Indonesia versi UNESCO yang ditetapkan pada tahun 2014. Hal ini tidak terlepas dari adanya sentra-sentra batik yang menjadi ikon dalam perkembangan industri batik di Kota Pekalongan termasuk di Sentra Batik Kauman dan Pesindon. Kedua sentra industri batik ini menjadi salah satu alternatif promosi batik dan rekreasi di Kota Pekalongan. Pelibatan aspek komunitas kreatif dan lingkungan kreatif berupa penyelenggaraan event mempengaruhi pemasukan dan kegiatan di Sentra Batik Kauman dan Pesindon sehingga mengalami perubahan. Artikel ini bertujuan untuk menganalisis perubahan di Sentra Batik Kauman dan Pesindon sejak penetapan Kota Pekalongan sebagai kota kreatif kerajinan. Ada beberapa aspek yang dilihat perubahannya yaitu: (1) pemeliharaan ekonomi kreatif, (2) komunitas kreatif, (3) lingkungan kreatif dan (4) penyelenggaraan event. Artikel ini menggunakan metode penelitian deskriptif kuantitatif dengan teknik analisis statistik deskriptif. Teknik analisis statistik deskriptif digunakan untuk menganalisis perubahan pada empat aspek tersebut. Survei yang dilakukan untuk penelitian ini adalah survei primer yang terdiri dari kuesioner, wawancara dan observasi serta survei sekunder dalam bentuk data. Hasilnya adalah pada aspek pemeliharaan ekonomi kreatif mengalami perubahan yaitu dari sisi SDM yang berinovasi, penyerapan tenaga kerja, jumlah perusahaan dan teknologi. Pada aspek komunitas kreatif yang mengalami perubahan yaitu dari sisi organisasi masyarakat. Untuk aspek lingkungan kreatif, yang mengalami perubahan yaitu dari sisi sarana untuk pusat pelatihan dan toko kerajinan. Sedangkan pada aspek lingkungan kreatif di Sentra Batik Pesindon yang mengalami perubahan hanya pada sarana untuk pusat pelatihan. Selanjutnya pada aspek penyelenggaraan event yaitu dari sisi program penyelenggaraan event untuk promosi mengalami perubahan.
\end{abstract}

Kata kunci: industri kreatif kerajinan; kota kreatif; perubahan

\begin{abstract}
Pekalongan City is the first creative city in the UNESCO version of the handicraft and folk arts category in Indonesia which was set in 2014. This is inseparable from the existence of batik centers that have become icons in the development of the batik industry in the City of Pekalongan including the Kauman and Pesindon Batik Centers. The two centers of the batik industry have become an alternative to batik promotion and recreation in Pekalongan City. The involvement of aspects of the creative community and the creative environment in the form of organizing events affected income and activities at the Kauman Batik Center and Pesindon so that it experienced changes. This article aims to analyze the changes at the Kauman and Pesindon Batik Centers since the designation of Pekalongan City as a creative city of crafts. There are several aspects of the change seen, namely: (1) maintenance of the creative economy, (2) creative community, (3) creative environment and (4) organizing events. This article uses descriptive quantitative research methods with descriptive statistical analysis techniques. Descriptive statistical analysis techniques are used to analyze changes in these four aspects. The primary data is collected through questionnaires, interviews and observations while secondary data is gathered from related agencies.. The result reveals that the aspects of maintaining the creative economy has been changing, in terms of innovation of human resources, employment, number of companies and technology. For creative community the changing isin terms of community organizations. For creative environment, the changing is in terms of facilities for training centers and craft shops. For creative environment, the changing at the Batik Center of Pesindon is only at the facilities for the training center. Laslty, for organizing events, event organizing program for promotion is also experiencing some changing.
\end{abstract}

Keywords: change; creative city; creative craft industry 


\section{PENDAHULUAN}

Charles Landry (1995) mengemukakan kota kreatif merupakan respon terhadap permasalahan yang dihadapi oleh beberapa kota saat terjadi transisi dalam menghadapi globalisasi ekonomi. Diperlukan kota yang memiliki iklim kondusif sehingga dapat mengatasi permasalahan khususnya kehidupan ekonomi pada suatu kota sehingga muncul gagasan kota kreatif. Pengembangan potensi ekonomi kreatif memegang peranan penting untuk menciptakan kota kreatif. Menurut Howkins (2001) ekonomi kreatif merupakan kegiatan ekonomi dalam masyarakat yang menghabiskan sebagian waktunya untuk menghasilkan ide. Artinya bahwa konsep kota kreatif ini merupakan konsep yang berbasis ide yang dapat menghasilkan kreativitas. Kota kreatif di Indonesia mulai dikembangkan dalam lokakarya ekonomi kreatif pada 2014 dengan membentuk Indonesia Creative Cities Network (ICCN) sebagai bagian dari program industri kreatif. Pemerintah Indonesia kemudian menetapkan beberapa kota di Indonesia untuk diusulkan ke jaringan kota kreatif dunia UNESCO. Mereka adalah Bandung, Yogyakarta, Surakarta dan Pekalongan. Kota Pekalongan merupakan kota yang terpilih menjadi kota kreatif pertama menurut UNESCO pada tahun 2014 kategori kerajinan dan kesenian rakyat.

Kota Pekalongan merupakan kota industri kreatif batik karena banyak sentra-sentra produksi batik yang tersebar di Kota Pekalongan. Industri di Kota Pekalongan menjadi salah satu penyumbang perekonomian terbesar selain sektor perdagangan. Trimargawati (2008) mengemukakan industri ini memberikan kontribusi besar terhadap kemajuan perekonomian di Kota Pekalongan dengan mayoritas berbentuk industri rumahan. Brand sebagai kota batik, perekonomian Kota Pekalongan ditumpu dari industri batik (RPJM Kota Pekalongan Tahun 2016-2021). Dalam RPJM Kota Pekalongan Tahun 2016-2021, sektor pariwisata terkait ekonomi kreatif tumbuh untuk mendukung pengembangan pariwisata kreatif yaitu dengan munculnya sentrasentra pusat wisata batik seperti di Sentra Batik Kauman dan Pesindon sebagai salah satu ikon pelestarian batik. Perkembangan industri batik di Kota Pekalongan tidak terlepas dari adanya peran sentra batik yang memproduksi batik. Pertumbuhan dan pengembangan ini salah satunya adalah dengan mengembangkan kawasan yang pada dasarnya merupakan sentra produksi batik di Kota Pekalongan yaitu di Sentra Batik Kauman dan Pesindon sebagai salah satu alternatif promosi batik. Sentra industri Batik Kauman juga merupakan sentra batik tertua di Kota Pekalongan yang mendorong bangkitnya sentra batik yang ada di sekitar seperti Sentra Batik Medono atau Kampung ATBM Medono.

Sentra Batik Kauman dan Pesindon memiliki peran dalam menciptakan ruang-ruang kreatif di bidang kerajinan batik. Keduanya memiliki komunitas masyarakat yaitu Paguyuban Kampung Batik Kauman dan Paguyuban Kampung Batik Pesindon. Aspek komunitas kreatif dan lingkungan kreatif memiliki peran dengan adanya penyelenggaraan event-event sebagai ajang promosi batik. Pengadaan event untuk promosi bidang kerajinan batik ini mempengaruhi para pengrajin di Sentra Batik Kauman dan Pesindon untuk terus melakukan inovasi dan memiliki peran aktif dalam pengadaan event tersebut. Sejak ditetapkan sebagai kota kreatif, perhatian Pemerintah Kota Pekalongan terhadap industri batik semakin meningkat dengan adanya program-program dan kegiatan untuk mempromosikan batik, salah satunya dengan munculnya kebijakan yang fokus pada pengembangan ekonomi kreatif sebagaimana yang terkandung dalam RPJM Kota Pekalongan Tahun 20162021. Selain itu, Sentra Batik Kauman dan Pesindon yang sebelumnya menjadi wadah mempelajari batik selain di Museum Batik semakin dikenal karena jika ada kunjungan untuk meninjau langsung proses pembuatan batik, pemkot setempat mengarahkan menuju kedua sentra industri batik tersebut.

Pada Oktober 2018, Walikota Pekalongan meresmikan program pembentukan Omah Kreatif Kauman sebagai sarana mewadahi kreativitas dan inovasi para pengrajin batik khususnya di Sentra Batik Kauman. Selain itu, dibuka Rembug Batik Nasional yang menjadi wadah untuk membahas permasalahan yang berhubungan dengan industri kerajinan batik. Sementara di Pesindon ada event Pesindon Fest yang diadakan oleh Paguyuban Kampung Batik Pesindon. Namun yang menjadi permasalahan adalah bahwa komunitas masyarakat di Pesindon ini belum sepenuhnya berpartisipasi aktif dalam pengembangan industri batik di Pesindon. Rencana program misalnya pengadaan showroom bersama seperti yang sudah dilakukan di Sentra Batik Kauman belum berjalan. Selain itu, belum ada kerjasama yang dilakukan baik antarpaguyuban di Kauman maupun di Pesindon untuk berbagi ide dan gagasan pengembangan industri batik. Pelibatan komunitas pada skala kota seperti Pekalongan Creative City Forum untuk mempromosikan kerajinan batik sudah dilakukan yaitu dengan menggandeng Paguyuban Kampung Batik Kauman, sedangkan di Paguyuban Kampung Batik Pesindon belum dilakukan. Jika melihat beberapa hal tersebut, hal ini kemudian mempengaruhi pemasukan dan kegiatan di Sentra Batik Kauman dan Pesindon yang kemudian menyebabkan perubahan pada aspek promosi dan pelibatan peran aktif masyarakat. Selain itu, setelah adanya penetapan sebagai kota kreatif kerajinan Pemerintah Kota Pekalongan memberikan perhatian lebih dengan 
adanya program-program yang mendorong Sentra Industri Batik di Kota Pekalongan ini bisa semakin berkembang melalui strategi promosi lewat event-event kreatif. Hal ini juga yang kemudian menyebabkan Sentra Industri Batik Kauman dan Pesindon mengalami perubahan sehingga muncul pertanyaan penelitian, bagaimana perubahan Sentra Industri Batik Kauman dan Pesindon dalam mendukung Penetapan Kota Pekalongan sebagai kota kreatif kerajinan. Artikel ini bertujuan untuk melihat perubahan pada sentra industri kerajinan batik Kauman dan Pesindon sejak penetapan Kota Pekalongan sebagai kota kreatif berbasis industri kerajinan batik. Untuk mencapai tujuan seperti yang sudah dikemukakan, diperlukan sasaran yaitu dengan mengidentifikasi kondisi Sentra Batik Kauman dan Pesindon sejak Kota Pekalongan ditetapkan sebagai kota kreatif yaitu tahun 2014 dan saat ini yaitu tahun 2018. Setelah itu, menganalisis perubahan yang terjadi di Sentra Batik Kauman dan Pesindon dalam mendukung Kota Pekalongan sebagai kota kreatif kerajinan batik. Ruang lingkup substansi dalam artikel ini yaitu terkait pemahaman tentang konsep kota kreatif dan teori industri kreatif kerajinan yang merupakan bagian dari ekonomi kreatif. Ekonomi kreatif yang dikembangkan dapat menjadi penggerak perekonomian yang kemudian dapat memunculkan ruangruang kreatif.

\section{KAJIAN TEORI}

\subsection{ASPEK KOTA KREATIF}

Kota kreatif pertama kali muncul pada tahun 1995 oleh Charles Landry dan Franco Bianchini yang dilatarbelakangi adanya permasalahan kota pada era globalisasi ekonomi. Dikemukakan oleh Landry (1995) bahwa kota dapat menjadi sebuah tempat bagi manusia berinteraksi menciptakan ide-ide baru. Ide-ide tersebut yang kemudian dapat menjadi solusi pemecahan dalam permasalahan ekonomi. Menurut Florida (2005), kota disebut kota kreatif jika adanya keberadaan kelas kreatif dengan kehadiran orang-orang kreatif yang menggunakan pikiran kreatifnya untuk memecahkan berbagai permasalahn yang dihadapi. Kota juga menjadi wadah aktivitas kreatif masyarakatnya. Menurut Charles Landry (2006), kota kreatif memiliki tiga aspek penting yaitu pemeliharaan dan pengembangan potensi ekonomi kreatif, komunitas kreatif (creative class) dan lingkungan kreatif. Menurut Richard Florida dalam bukunya Cities and The Creatives Class (2005), kota kreatif ditentukan oleh tiga faktor utama yaitu talenta, toleransi dan teknologi. Faktor talenta meliputi aspek pekerja kreatif, budaya meneliti, modal sumber daya manusia. Faktor toleransi meliputi aspek sikap, nilai dan ekspresi diri. Aspek sikap dilihat dari sikap terhadap minoritas, keterbukaan terhadap orang-orang yang memiliki latar belakang yang berbeda, kesempatan pekerjaan yang tersedia bagi warga yang bukan berasal dari daerah tersebut. Aspek nilai diukur dari sejauh mana nilai-nilai tradisional asli bisa hidup dan harmonis berdampingan dengan nilai-nilai modern. Aspek ekspresi diri diukur dari sejauh mana sebuah kota mampu menghormati hak-hak individu dalam mengekspresikan dirinya. Faktor teknologi meliputi aspek kecanggihan teknologi. Selain itu, Evans,dkk (2006) juga memberikan aspek penting dari kota kreatif antara lain yaitu kualitas manusia yang kreatif, dukungan dari wirausaha dan inovasi kreatif untuk peningkatan perekonomian, ruang sebagai wadah kegiatan kreatif sekaligus menjadi stimulan masyarakat untuk berkreativitas, dukungan kebijakan politik yang terkandung dalam visi pembangunan serta konektivitas infrastruktur yang baik. Dari beberapa teori tersebut, kemudian dihasilkan sintesa aspek kota kreatif yaitu pemeliharaan ekonomi kreatif, komunitas kreatif dan lingkungan kreatif (lihat Tabel 1).

Tabel 1. Sintesis Aspek Kota Kreatif

\begin{tabular}{|c|c|c|c|c|}
\hline Landry (2008) & Florida (2004 & & Evans,dkk (2006) & Hasil Sintesis \\
\hline $\begin{array}{l}\text { Pemeliharaan dan } \\
\text { pengembangan ekonomi } \\
\text { kreatif }\end{array}$ & $\begin{array}{l}\text { Modal sumber } \\
\text { manusia } \\
\text { Pekerja kreatif } \\
\text { Teknologi }\end{array}$ & daya & $\begin{array}{l}\text { Kualitas manusia yang } \\
\text { kreatif } \\
\text { Dukungan wirausaha } \\
\text { dan inovasi kreatif }\end{array}$ & $\begin{array}{l}\text { Pemeliharaan ekonomi } \\
\text { kreatif }\end{array}$ \\
\hline Komunitas kreatif & $\begin{array}{l}\text { Keterbukaan } \\
\text { keanekaragaman } \\
\text { Budaya meneliti }\end{array}$ & dan & - & Komunitas kreatif \\
\hline Lingkungan kreatif & - & & $\begin{array}{l}\text { Ruang sebagai wadah } \\
\text { kegiatan kreatif } \\
\text { Konektivitas infrastruktur }\end{array}$ & Lingkungan kreatif \\
\hline
\end{tabular}

Sumber : Landry (2008), Florida (2004), Evans,dkk (2006) 


\subsection{PRASYARAT KOTA KREATIF}

Landry (2006) juga menjelaskan bahwa terdapat beberapa syarat untuk mewujudkan kota kreatif yaitu kualitas personal, kepemimpinan, keragaman jenis dan bakat manusida, budaya organisasi, identitas lokal, ruang perkotaan dan fasilitas serta dinamika jejaring.

a) Kualitas personal, merupakan hal yang bersifat individu bahwa kota kreatif berisi individu-individu kreatif yaitu orang-orang yang dapat menyelesaikan masalah, berpikir secara terbuka dan fleksibel dan orang-orang yang mau mengambil resiko.

b) Kepemimpinan, dibutuhkan untuk mengembangkan kota kreatif yang dapat berkaitan dengan kebijakan kota kreatif.

c) Keragaman dan bakat yang bervariasi, merupakan indikasi bahwa kota akan lebih mudah untuk mengembangkan kreativitasnya. Menurut Landry (2006), keragaman yang tinggi dapat menjadi pertukaran ide untuk berinovasi. Keragaman kondisi sosial budaya juga tidak terlepas dari pengaruh suatu pendatang ke dalam suatu kota. Para pendatang dapat membawa sesuatu yang baru yang dapat diaplikasikan di kota tersebut untuk dapat mengembangkan potensi ataupun menyelesaikan masalah. Namun, penduduk asli kota juga memiliki peran penting untuk mempertahankan lokalitas, kreativitas dan rasa memiliki.

d) Budaya organisasi, organisasi dapat menunjang kreativitas. Kreativitas tanpa organisasi tidak akan cukup untuk mengolah sumber daya yang ada di dalam kota. Semakin banyak organisasi-organisasi dalam suatu sistem akan meningkatkan kemampuan untuk berinovasi.

e) Identitas lokal, identitas budaya lokal dan kebanggaan terhadap kebudayaan lokal merupakan hal yang penting agar terjadi pembaruan di bidang ekonomi, komunitas dan lingkungan.

f) Ruang perkotaan dan fasilitas, menurut Landry (2006) ada dua faktor penting bagi kota kreatif yaitu infrastruktur lunak dan infrastruktur keras. Infrastruktur lunak terdiri dari jaringan sosial dan ruang yang mewadahi interaksi orang-orang kreatif. Sedangkan infrastruktur keras terdiri dari lingkungan fisik berupa taman, galeri seni, ruang pertunjukan dan museum.

g) Kerjasama, memiliki keterkaitan dengan kreativitas. Semakin banyak kerjasama di dalam suatu kota, semakin besar pula kapasitas untuk menciptakan inovasi. Kerjasama/kemitraan terdiri dari dua hal yaitu kerjasama di dalam kota dan kerjasama dengan hubungan ke luar. Adanya organisasi-organisasi juga dapat menjadi wadah melakukan kerjasama, sehingga semakin banyaknya organisasi di dalam kota, akan meningkatkan kemampuan untuk menciptakan inovasi yang kemudian berujung pada kreativitas.

Pada tahun 2004, UNESCO meliris Creative City Network (Jaringan Kota Kreatif) untuk meningkatkan cakupan jejaring ke seluruh dunia dan mendorong kerjasama antarkota yang berkomitmen berinvestasi di kreativitas sebagai pendorong pembangunan perkotaan berkelanjutan, inklusi sosial dan budaya. Ada beberapa kriteria dari UNESCO (2004) terkait kota kreatif kerajinan yaitu:

a) Tradisi tahan lama dalam bentuk tertentu

b) Kerajinan atau kesenian rakyat

c) Produksi kerajinan dan kesenian rakyat kontemporer

d) Kehadiran kuat pembuat kerajinan dan seniman lokal

e) Pusat pelatihan yang berkaitan dengan kerajinan tangan dan kesenian rakyat

f) Upaya mempromosikan kerajinan dan kesenian rakyat (festival, pameran, pasar)

g) Infrastruktur yang relevan dengan kerajinan dan kesenian rakyat misalnya museum, toko kerajinan tangan, pameran seni lokal.

Dari prasyarat kota kreatif dan kriteria kota kreatif yang telah dikemukakan, dihasilkan sintesa prasyarat kota kreatif yang kemudian disandingkan dengan aspek kota kreatif sehingga menghasilkan variabel berupa pemeliharaan ekonomi kreatif, komunitas kreatif, lingkungan kreatif dan penyelenggaraan event (lihat Tabel 2 dan tabel 3). 
Tabel 2. Sintesis Prasyarat Kota Kreatif Kerajinan

\begin{tabular}{|c|c|c|}
\hline Prasyarat Kota Kreatif Landry (2006) & Kriteria Kota Kreatif UNESCO (2004) & Hasil Sintesis \\
\hline- & $\begin{array}{l}\text { Kehadiran pembuat kerajinan dan } \\
\text { seniman lokal }\end{array}$ & $\begin{array}{l}\text { Pembuat kerajinan dan seniman } \\
\text { lokal }\end{array}$ \\
\hline Kepemimpinan & - & Kepemimpinan \\
\hline Keragaman dan bakat yang bervariasi & - & $\begin{array}{l}\text { Keragaman manusia dan bakat } \\
\text { yang bervariasi }\end{array}$ \\
\hline $\begin{array}{l}\text { Budaya organisasi } \\
\text { Kerjasama }\end{array}$ & - & $\begin{array}{l}\text { Organisasi yang memungkinkan } \\
\text { menjadi wadah kerjasama }\end{array}$ \\
\hline Identitas lokal & $\begin{array}{l}\text { Tradisi lama dalam bentuk tertentu } \\
\text { Produksi kerajinan dan kesenian rakyat }\end{array}$ & Identitas lokal \\
\hline Ruang perkotaan dan fasilitas & $\begin{array}{l}\text { Pusat pelatihan } \\
\text { Infrastruktur yang relevan }\end{array}$ & Ruang perkotaan dan fasilitas \\
\hline - & $\begin{array}{l}\text { Penyelenggaraan event } \\
\text { - Event untuk promosi (festival, } \\
\text { pameran dll) }\end{array}$ & Penyelenggaraan event \\
\hline
\end{tabular}

Tabel 3. Sintesis Kota Kreatif Kerajinan

\begin{tabular}{|c|c|c|}
\hline Sintesis Aspek Kota Kreatif & Prasyarat Kota Kreatif & Hasil Sintesis \\
\hline Pemeliharaan ekonomi kreatif & & Pemeliharaan ekonomi kreatif \\
\hline - Modal SDM kreatif lokal & - Identitas lokal & \\
\hline & - Pembuat kerajinan & \\
\hline $\begin{array}{l}\text { - Dukungan wirausaha dan inovasi } \\
\text { kreatif } \\
\text { - Teknologi }\end{array}$ & & \\
\hline Komunitas kreatif & $\begin{array}{l}\text { Keragaman manusia dan bakat yang } \\
\text { bervariasi } \\
\text { Organisasi yang memungkinkan } \\
\text { menjadi wadah kerjasama }\end{array}$ & Komunitas kreatif \\
\hline \multirow{2}{*}{$\begin{array}{l}\text { Lingkungan kreatif } \\
-\quad \text { Ruang sebagai wadah kegiatan } \\
\text { kreatif } \\
-\quad \text { Konektivitas infrastruktur }\end{array}$} & $\begin{array}{l}\text { - Ruang perkotaan dan fasilitas } \\
\text { - Infrastuktur yang relevan }\end{array}$ & Lingkungan kreatif \\
\hline & $\begin{array}{l}\text { Penyelenggaraan event } \\
\text { - Event untuk promosi (festival, } \\
\text { pameran dll) } \\
\text { Kepemimpinan }\end{array}$ & Penyelenggaraan event \\
\hline
\end{tabular}

\subsection{INDUSTRI KREATIF KERAJINAN}

Menurut Setiawan (2004), sentra merupakan kesatuan fungsional secara fisik yaitu lahan, geografis, infrastruktur, kelembagaan dan sumber daya manusia yang berpotensi berkembangnya kegiatan ekonomi. Menurut UNCTAD dan UNDP (2008) inti atau jantung ekonomi kreatif adalah industri kreatif yang melakukan proses penciptaan melalui penelitian dan pengembangan. Menurut UU Nomor 3 Tahun 2014 tentang perindustrian, industri adalah seluruh bentuk kegiatan ekonomi yang mengolah bahan baku dan/atau memanfaatkan sumber daya industri sehingga menghasilkan barang yang mempunyai nilai tambah atau manfaat lebih tinggi termasuk jasa industri. Industri kreatif menurut Departemen Perdagangan RI (2008) adalah industri yang berasal dari pemanfaatan kreativitas, keterampilan serta bakat individu untuk menciptakan kesejahteraan dan lapangan pekerjaan dengan menghasilkan dan memberdayakan daya kreasi dan daya cipta individu tersebut. Departemen Perdagangan RI menyebutkan ada beberapa karakeristik industri kreatif di antaranya yaitu:

a) Fruktuasi pertumbuhan nilai tambah terjadi hampir pada seluruh sub sektor industri kreatif

b) Diikuti fruktuasi pertumbuhan jumlah perusahaan 
c) Pertumbuhan penyerapan tenaga kerja

d) Memiliki teknologi

Pemerintah membuat lima pilar sebagai pembentuk industri kreatif yaitu industri yang terlibat dalam produksi, teknologi sebagai pendukung kreativitas, sumber daya alam, kelembagaan dan lembaga intermediasi keuangan. Menurut Howkins (2001) juga menyebutkan ada beberapa karakteristik dari industri kreatif di antaranya yaitu:

a) Kolaborasi antara berbagai aktor yang berperan dalam industri kreatif yaitu cendekiawan, dunia usaha dan pemerintah.

b) Berbasis ide atau gagasan

c) Pengembangan tidak terbatas dalam berbagai bidang usaha

d) Konsep yang dibangun bersifat relatif

Industri kreatif memiliki 16 sub sektor, di mana industri kerajinan merupakan salah satu dari 16 sub sektor industri kreatif. UNIDO (2007) menjelaskan industri kerajinan merupakan kegiatan ekonomi yang menghasilkan produk berbasis tradisi, budaya serta sejarah. Inputnya yaitu budaya, kreativitas pelaku usaha, inovasi produk, bahan baku dan teknologi. Menurut Soeprapto (1985) kerajinan merupakan keterampilan tangan yang menghasilkan barang bermutu seni, maka dalam prosesnya dibuat dengan rasa keindahan dan dengan ide-ide yang murni sehingga menghasilkan produk yang berkualitas yang mempunyai bentuk indah dan menarik. Unsur kerajinan antara lain yaitu adanya penciptaan suatu barang, penekanan pada keterampilan tenaga manusia dan barang yang dihasilkan untuk memenuhi kebutuhan dan bernilai seni.

Dari hasil tinjauan teori terkait industri kreatif kerajinan kemudian didapatkan hasil sintesis teori industri kreatif berbasis kerajinan yaitu meliputi 1) terdapatnya sarana pendukung industri kreatif, 2) penciptaan barang yang mengandalkan inovasi dan kreativitas SDM, 3) penyerapan tenaga kerja, 4) pertumbuhan jumlah perusahaan, 5) bahan baku dan teknologi, dan 6) adanya kolaborasi kelembagaan dengan berbagai aktor industri kreatif. Dari ke enam sintesis teori industri kreatif kerajinan ini kemudian disilangkan dengan sintesis teori kota kreatif kerajinan sehingga menghasilkan parameter dari masing-masing variabel dan sub variabelnya (lihat Tabel 4).

Tabel 4. Variabel, Sub Variabel dan Parameter Sentra Industri Kreatif Kerajinan Ditinjau dari Konsep Kota Kreatif Kerajinan

\begin{tabular}{|c|c|c|}
\hline Variabel & Sub Variabel & Parameter \\
\hline \multirow[t]{5}{*}{ Pemeliharaan ekonomi kreatif } & Modal SDM kreatif lokal & SDM yang mengandalkan inovasi dan kreativitas \\
\hline & $\begin{array}{l}\text { Dukungan wirausaha dan inovasi } \\
\text { kreatif }\end{array}$ & $\begin{array}{l}\text { Dukungan wirausaha dan inovasi kreatif yang dapat } \\
\text { menyerap tenaga kerja }\end{array}$ \\
\hline & & $\begin{array}{l}\text { Dukungan wirausaha dan inovasi kreatif yang dapat } \\
\text { meningkatkan pertumbuhan jumlah perusahaan }\end{array}$ \\
\hline & & $\begin{array}{l}\text { Kolaborasi kelembagaan dengan berbagai aktor } \\
\text { industri kreatif }\end{array}$ \\
\hline & Teknologi & Teknologi untuk pemanfaatan bahan baku \\
\hline \multirow[t]{2}{*}{ Komunitas kreatif } & $\begin{array}{l}\text { Keanekaragaman dan bakat } \\
\text { bervariasi }\end{array}$ & $\begin{array}{l}\text { Ragam latar belakang masyarakat sebagai tenaga } \\
\text { kerja industri kreatif }\end{array}$ \\
\hline & $\begin{array}{l}\text { Organisasi yang memungkinkan } \\
\text { menjadi wadah kerjasama }\end{array}$ & Organisasi masyarakat \\
\hline \multirow[t]{2}{*}{ Lingkungan kreatif } & Ruang sebagai wadah berkreativitas & Sarana untuk pusat pelatihan kerajinan \\
\hline & $\begin{array}{l}\text { Infrastruktur yang relevan dengan } \\
\text { kerajinan }\end{array}$ & $\begin{array}{l}\text { Infrastruktur yang relevan dengan kerajinan berupa } \\
\text { museum, toko kerajinan tangan, pasar, galeri seni }\end{array}$ \\
\hline Penyelenggaraan event & Event untuk promosi & $\begin{array}{l}\text { Terdapat program penyelenggaraan event untuk } \\
\text { promosi berupa festival, pameran }\end{array}$ \\
\hline
\end{tabular}

\section{METODE PENELITIAN}

Metode penelitian ini memuat ruang lingkup wilayah dan analisis yang digunakan untuk mengetahui perubahan pada sentra industri kerajinan batik ditinjau dari konsep kota kreatif kerajinan. 


\subsection{RUANG LINGKUP WILAYAH}

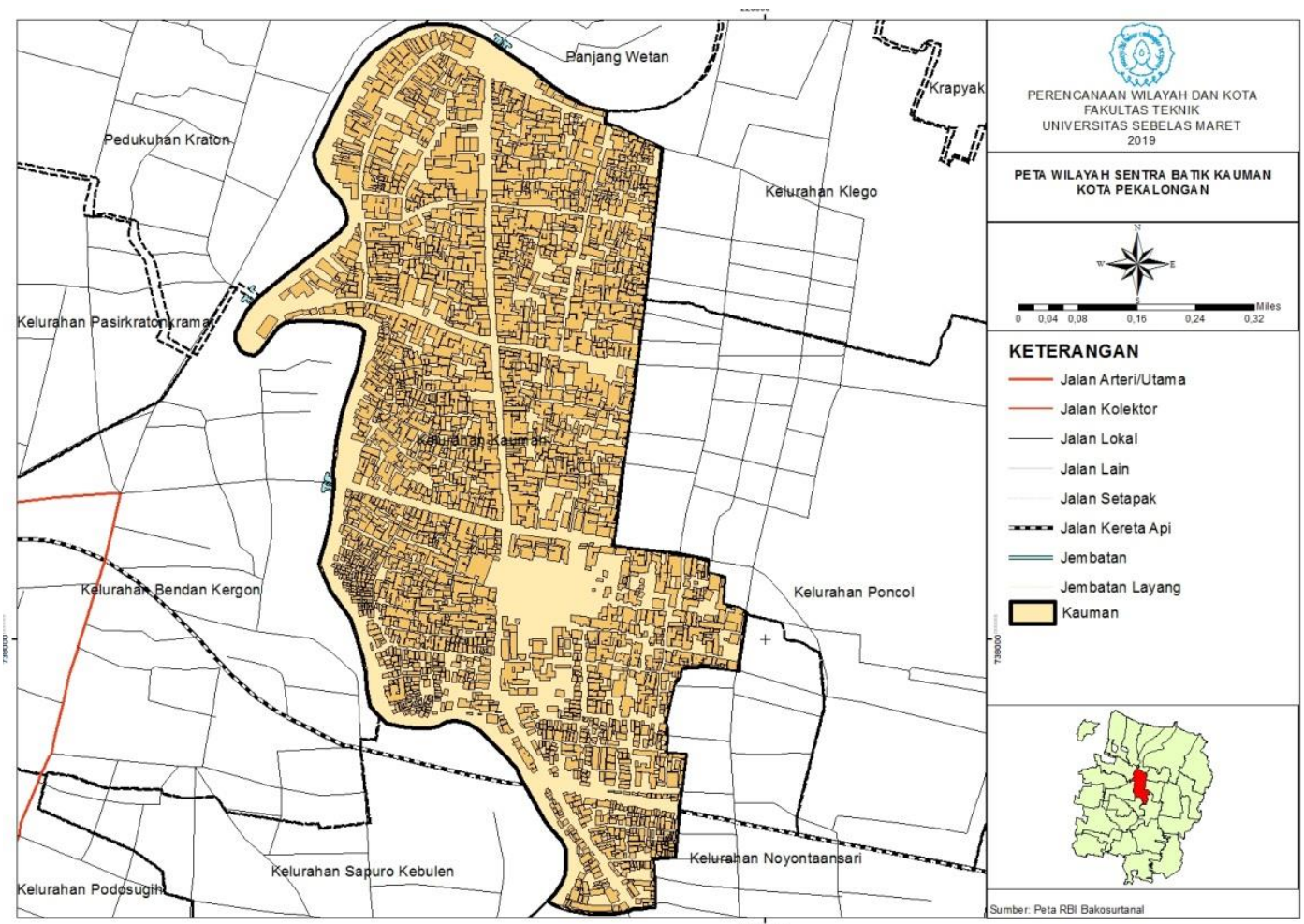

Gambar 1. Peta Wilayah Sentra Batik Kauman

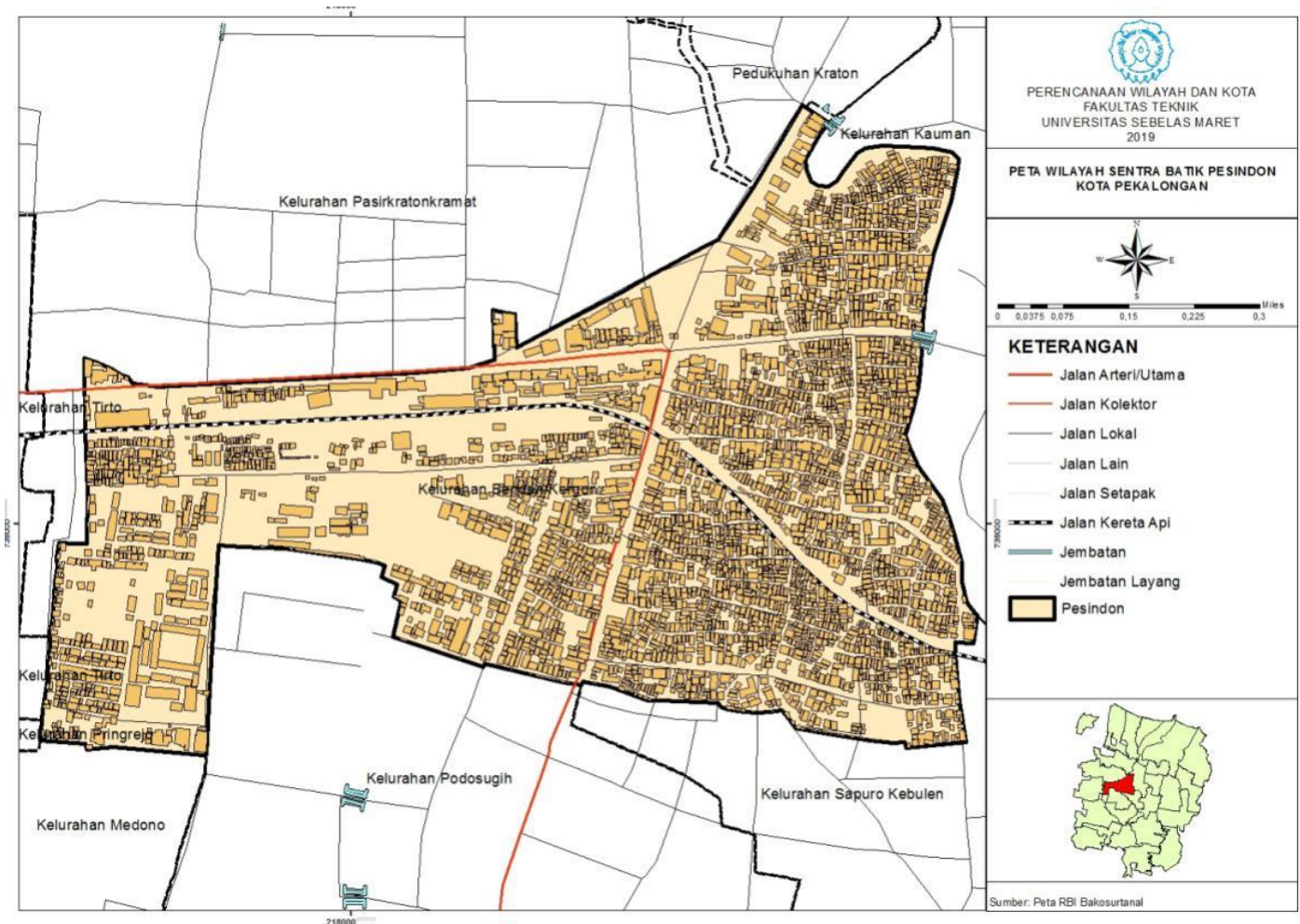

Gambar 2. Peta Wilayah Sentra Batik Pesindon 
Ruang lingkup wilayah merupakan Sentra Industri Batik Kauman dan Pesindon di Kota Pekalongan, Jawa Tengah. Sentra Batik Kauman berada di Kelurahan Kauman, Kecamatan Pekalongan Timur yang merupakan sentra kerajinan batik yang menjadi salah satu ikon Kota Pekalongan sebagai kota batik (Gambar 1). Sentra ini merupakan salah satu yang memiliki banyak pengusaha dan pengrajin batik. Sedangkan Pesindon berada di Kelurahan Bendan Kergon, Kecamatan Pekalongan Barat yang juga merupakan wilayah yang didominasi oleh home industry batik (Gambar 2). Pesindon dan Kauman merupakan sentra industri batik yang berupaya untuk terus melestarikan budaya batik dengan menawarkan wisata belanja batik. Pelestarian budaya batik ini juga yang kemudian mendukung penetapan Kota Pekalongan sebagai kota kreatif dengan adanya event-event bidang kerajinan batik serta pelibatan komunitas masyarakat.

\subsection{TEKNIK PENGUMPULAN DATA}

Untuk melihat perubahan pada sentra industri kerajinan batik, dilihat dari empat variabel yaitu meliputi pemeliharaan ekonomi kreatif, komunitas kreatif, lingkungan kreatif dan penyelenggaraan event. Masing-masing variabel memiliki sub variabel yang kemudian dijabarkan lagi ke dalam parameter penelitian. Setiap parameter memiliki indikator untuk melihat perubahannya yaitu indikator (1) dan indikator (2) (lebih lanjut akan dijelaskan pada Tabel 5). Ruang lingkup waktu untuk melihat kondisi perubahannya yaitu tahun 2014 dan tahun 2018. Teknik pengumpulan data menggunakan teknik pengumpulan data primer dan sekunder. Pengumpulan data primer yaitu dengan pembagian kuesioner, observasi dan wawancara. Dalam artikel ini kuesioner ditujukan kepada para pelaku industri batik untuk mengetahui persepsi mereka terhadap industri batik yaitu meliputi modal SDM yang melakukan inovasi dan ragam inovasi yang diciptakan, teknologi yang digunakan untuk memanfaatkan bahan baku lokal dan data asal pekerja di Sentra Batik Kauman dan Pesindon. Sampel pelaku usaha batik di Kauman berjumlah 45 responden dan di Pesindon berjumlah 32 responden dengan menggunakan teknik simple random sampling. Observasi dilakukan untuk mengetahui kondisi eksisting lokasi penelitian terkait sarana dan prasarana yang relevan dengan kerajinan meliputi sarana sebagai pusat pelatihan batik dan toko kerajinan batik. Sedangkan wawancara dilakukan untuk melengkapi data deskriptif terkait industri kerajinan batik dan kota kreatif kerajinan yaitu peran lembaga dan aktor industri kreatif di Kota Pekalongan, program atau kegiatan komunitas dan penyelenggaraan event. Pengumpulan data sekunder yaitu melalui media perantara seperti dokumen-dokumen yang dimiliki pihak lain atau melalui studi literatur yaitu meliputi data jumlah tenaga kerja industri batik di Sentra Batik Kauman dan Pesindon, data jumlah unit usaha Batik Kauman dan Pesindon serta data penyelenggaraan event di Kota Pekalongan sebagai data tambahan untuk melengkapi penelitian ini.

\subsection{TEKNIK ANALISIS}

Setelah data terkumpul dari empat variabel yang sudah disebutkan, kemudian dilakukan teknik analisis data dengan menggunakan teknik analisis deskriptif kuantitatif. Teknik analisis ini bermaksud untuk mendeskripsikan data yang telah diperoleh tanpa melakukan generalisasi. Analisis ada tidaknya perubahan dengan menggunakan indikator perubahan (1) dan (2) yang kemudian dideskripsikan penyebab dari ada dan tidaknya perubahan (Tabel 5). Hasil akhir analisis tidak bersifat secara keseluruhan, artinya bahwa identifikasi perubahan dilakukan per komponen.

Tabel 5. Variabel, Sub Variabel, Parameter dan Indikator Sentra Industrti Batik Ditinjau dari Kota Kreatif Kerajinan

\begin{tabular}{|c|c|c|c|c|c|c|}
\hline \multirow{2}{*}{ Variabel } & \multirow{2}{*}{ Sub Variabel } & \multirow{2}{*}{ Parameter } & \multicolumn{2}{|c|}{ Indikator (2014) } & \multicolumn{2}{|c|}{ Indikator (2018) } \\
\hline & & & Skor (1) & Skor (2) & Skor (1) & Skor (2) \\
\hline \multirow[t]{3}{*}{$\begin{array}{l}\text { Pemeliharaan } \\
\text { ekonomi kreatif }\end{array}$} & $\begin{array}{l}\text { Modal SDM kreatif } \\
\text { lokal }\end{array}$ & $\begin{array}{l}\text { SDM yang } \\
\text { mengandalkan } \\
\text { inovasi dan } \\
\text { kreativitas }\end{array}$ & $\begin{array}{l}\text { Tidak ada } \\
\text { diversifikasi } \\
\text { produk }\end{array}$ & $\begin{array}{l}\text { Ada diversifikasi } \\
\text { produk }\end{array}$ & $\begin{array}{l}\text { Tidak ada } \\
\text { diversifikasi } \\
\text { produk }\end{array}$ & $\begin{array}{l}\text { Ada diversifikasi } \\
\text { produk }\end{array}$ \\
\hline & $\begin{array}{l}\text { Dukungan } \\
\text { wirausaha dan } \\
\text { inovasi kreatif }\end{array}$ & $\begin{array}{l}\text { Dapat menyerap } \\
\text { tenaga kerja }\end{array}$ & $\begin{array}{l}\text { Ada/ tidak ada } \\
\text { penyerapan } \\
\text { tenaga kerja }\end{array}$ & $\begin{array}{l}\text { Adanya } \\
\text { peningkatan } \\
\text { jumlah tenaga } \\
\text { kerja }\end{array}$ & $\begin{array}{l}\text { Ada/ tidak ada } \\
\text { penyerapan } \\
\text { tenaga kerja }\end{array}$ & $\begin{array}{l}\text { Adanya } \\
\text { peningkatan } \\
\text { jumlah tenaga } \\
\text { kerja }\end{array}$ \\
\hline & & $\begin{array}{l}\text { Dapat } \\
\text { meningkatkan } \\
\text { pertumbuhan } \\
\text { jumlah } \\
\text { perusahaan }\end{array}$ & $\begin{array}{l}\text { Ada/ tidak ada } \\
\text { perubahan }\end{array}$ & $\begin{array}{l}\text { Ada } \\
\text { peningkatan } \\
\text { jumlah } \\
\text { perusahaan }\end{array}$ & $\begin{array}{l}\text { Ada/ tidak ada } \\
\text { perubahan }\end{array}$ & $\begin{array}{l}\text { Ada } \\
\text { peningkatan } \\
\text { jumlah } \\
\text { perusahaan }\end{array}$ \\
\hline
\end{tabular}




\begin{tabular}{|c|c|c|c|c|c|c|}
\hline \multirow{2}{*}{ Variabel } & \multirow{2}{*}{ Sub Variabel } & \multirow{2}{*}{ Parameter } & \multicolumn{2}{|c|}{ Indikator (2014) } & \multicolumn{2}{|c|}{ Indikator (2018) } \\
\hline & & & Skor (1) & Skor (2) & Skor (1) & Skor (2) \\
\hline \multirow{4}{*}{$\begin{array}{l}\text { Komunitas } \\
\text { kreatif }\end{array}$} & & $\begin{array}{l}\text { Kolaborasi } \\
\text { kelembagaan } \\
\text { dengan berbagai } \\
\text { aktor industri } \\
\text { kreatif }\end{array}$ & $\begin{array}{ll}\text { Belum ada } \\
\text { kolaborasi }\end{array}$ & $\begin{array}{l}\text { Terdapat } \\
\text { kolaborasi }\end{array}$ & $\begin{array}{l}\text { Belum ada } \\
\text { kolaborasi }\end{array}$ & $\begin{array}{l}\text { Terdapat } \\
\text { kolaborasi }\end{array}$ \\
\hline & Teknologi & $\begin{array}{l}\text { Teknologi untuk } \\
\text { pemanfaatan } \\
\text { bahan baku lokal }\end{array}$ & $\begin{array}{l}\text { Menggunakan } \\
\text { teknologi } \\
\text { sederhana }\end{array}$ & $\begin{array}{l}\text { Menggunakan } \\
\text { teknologi } \\
\text { sederhana dan } \\
\text { modern }\end{array}$ & $\begin{array}{l}\text { Menggunakan } \\
\text { teknologi } \\
\text { sederhana }\end{array}$ & $\begin{array}{l}\text { Menggunakan } \\
\text { teknologi } \\
\text { sederhana dan } \\
\text { modern }\end{array}$ \\
\hline & $\begin{array}{l}\text { Keanekaragaman } \\
\text { dan bakat } \\
\text { bervariasi }\end{array}$ & $\begin{array}{l}\text { Ragam latar } \\
\text { belakang } \\
\text { masyarakat } \\
\text { sebagai tenaga } \\
\text { kerja industri } \\
\text { kreatif }\end{array}$ & $\begin{array}{l}\text { Berasal dai } \\
\text { dalam kota }\end{array}$ & $\begin{array}{l}\text { Berasal dari } \\
\text { dalam maupun } \\
\text { luar }\end{array}$ & $\begin{array}{l}\text { Berasal dai } \\
\text { dalam kota }\end{array}$ & $\begin{array}{l}\text { Berasal dari } \\
\text { dalam maupun } \\
\text { luar }\end{array}$ \\
\hline & $\begin{array}{l}\text { Organisasi yang } \\
\text { memungkinkan } \\
\text { menjadi wadah } \\
\text { kerjasama }\end{array}$ & $\begin{array}{l}\text { Organisasi } \\
\text { masyarakat }\end{array}$ & $\begin{array}{l}\text { Terdapat } \\
\text { organisasi untuk } \\
\text { mendukung } \\
\text { industri kreatif }\end{array}$ & $\begin{array}{l}\text { Terdapat } \\
\text { organisasi dan } \\
\text { memungkinkan } \\
\text { melakukan } \\
\text { kerjasama }\end{array}$ & $\begin{array}{l}\text { Terdapat } \\
\text { organisasi } \\
\text { untuk } \\
\text { mendukung } \\
\text { industri kreatif }\end{array}$ & $\begin{array}{l}\text { Terdapat } \\
\text { organisasi dan } \\
\text { memungkinkan } \\
\text { melakukan } \\
\text { kerjasama }\end{array}$ \\
\hline \multirow[t]{2}{*}{$\begin{array}{l}\text { Lingkungan } \\
\text { kreatif }\end{array}$} & $\begin{array}{l}\text { Ruang sebagai } \\
\text { wadah } \\
\text { berkreativitas }\end{array}$ & $\begin{array}{l}\text { Sarana untuk } \\
\text { pusat pelatihan } \\
\text { kerajinan }\end{array}$ & $\begin{array}{l}\text { Tidak ada/ ada } \\
\text { workshop di } \\
\text { masing-masing } \\
\text { unit }\end{array}$ & $\begin{array}{lr}\text { Sudah ada } \\
\text { workshop yang } \\
\text { dikelola } \\
\text { bersama }\end{array}$ & $\begin{array}{l}\text { Tidak ada/ } \\
\text { ada workshop } \\
\text { di masing- } \\
\text { masing unit }\end{array}$ & $\begin{array}{lr}\text { Sudah ada } \\
\text { workshop yang } \\
\text { dikelola } \\
\text { bersama }\end{array}$ \\
\hline & $\begin{array}{l}\text { Infrastruktur yang } \\
\text { relevan dengan } \\
\text { kerajinan }\end{array}$ & $\begin{array}{l}\text { Toko kerajinan } \\
\text { tangan }\end{array}$ & $\begin{array}{l}\text { Tidak ada/ ada } \\
\text { showroom pada } \\
\text { masing-masing } \\
\text { unit }\end{array}$ & $\begin{array}{l}\text { Sudah ada } \\
\text { showroom yang } \\
\text { dikelola secara } \\
\text { bersama }\end{array}$ & $\begin{array}{l}\text { Tidak adal } \\
\text { ada } \\
\text { showroom } \\
\text { pada masing- } \\
\text { masing unit }\end{array}$ & $\begin{array}{l}\text { Sudah ada } \\
\text { showroom yang } \\
\text { dikelola secara } \\
\text { bersama }\end{array}$ \\
\hline $\begin{array}{l}\text { Penyelenggara- } \\
\text { an event }\end{array}$ & $\begin{array}{l}\text { Event } \\
\text { promosi }\end{array}$ & $\begin{array}{lr}\text { Program } & \text { berupa } \\
\text { festival } & \text { atau } \\
\text { pameran } & \end{array}$ & $\begin{array}{lr}\text { Belum ada } & \text { program event } \\
\text { festival atau } \\
\text { pameran }\end{array}$ & $\begin{array}{lr}\text { Terdapat } & \\
\text { maksimal } & 3 \\
\text { program } & \text { event } \\
\text { festival } & \text { atau } \\
\text { pameran } & \end{array}$ & $\begin{array}{l}\text { Belum ada } \\
\text { program event } \\
\text { festival atau } \\
\text { pameran }\end{array}$ & $\begin{array}{lr}\text { Terdapat } & \\
\text { maksimal } & 3 \\
\text { program } & \text { event } \\
\text { festival } & \text { atau } \\
\text { pameran } & \end{array}$ \\
\hline
\end{tabular}

Tabel 6. Analisis perubahan

\begin{tabular}{cccc} 
No. & \multicolumn{2}{l}{ Indikator Perubahan } & Keterangan \\
\hline 1. & $(1)$ & $(2)$ & Ada perubahan positif \\
2. & $(2)$ & $(1)$ & Ada perubahan negatif \\
3. & $(1)$ & $(1)$ & Tidak ada perubahan \\
\hline
\end{tabular}

Setelah dilakukan analisis perubahan dari masing-masing sentra industri, kemudian didapatkan hasil mana saja parameter dari variabel yang mengalami perubahan dan tidak mengalami perubahan dari Sentra Batik Kauman dan Pesindon sehingga di antara keduanya dapat dilihat hasil dari aspek yang mendukung penetapan Kota Pekalongan sebagai kota kreatif kerajinan (Tabel 6).

\section{HASIL DAN PEMBAHASAN}

Berdasarkan data-data yang diperoleh, maka dapat disimpulkan hasilnya sebagai berikut. 


\subsection{PERUBAHAN ASPEK PEMELIHARAAN EKONOMI KREATIF}

Pemeliharaan ekonomi kreatif memiliki tiga sub aspek yaitu modal SDM kreatif lokal, dukungan wirausaha dan inovasi kreatif dan teknologi. Masing-masing sub aspek tersebut memiliki parameter yang menjadi tolak ukur dalam menilai ada dan tidak adanya perubahan (Tabel 7).

Tabel 7. Perubahan Aspek Pemeliharaan Ekonomi Kreatif

\begin{tabular}{|c|c|c|c|c|c|c|c|c|}
\hline \multirow{2}{*}{ Aspek } & \multirow{2}{*}{ Sub Aspek } & \multirow{2}{*}{ Parameter } & \multicolumn{3}{|c|}{ Kauman } & \multicolumn{3}{|c|}{ Pesindon } \\
\hline & & & 2014 & 2018 & Hasil & 2014 & 2018 & Hasil \\
\hline \multirow[t]{5}{*}{$\begin{array}{l}\text { Pemeliharaan } \\
\text { ekonomi kreatif }\end{array}$} & $\begin{array}{l}\text { Modal SDM } \\
\text { kreatif lokal }\end{array}$ & $\begin{array}{l}\text { SDM yang } \\
\text { melakukan } \\
\text { inovasi }\end{array}$ & 1 & 2 & $\begin{array}{c}\text { Ada } \\
\text { perubahan }\end{array}$ & 1 & 2 & $\begin{array}{c}\text { Ada } \\
\text { perubahan }\end{array}$ \\
\hline & $\begin{array}{l}\text { Dukungan } \\
\text { wirausaha }\end{array}$ & Penyerapan & 1 & 2 & $\begin{array}{c}\text { Ada } \\
\text { perubahan }\end{array}$ & 1 & 2 & $\begin{array}{c}\text { Ada } \\
\text { perubahan }\end{array}$ \\
\hline & kreatif & $\begin{array}{l}\text { pertumbuhan } \\
\text { jumlah } \\
\text { perusahaan }\end{array}$ & 1 & 2 & $\begin{array}{c}\text { Ada } \\
\text { perubahan }\end{array}$ & 1 & 2 & $\begin{array}{c}\text { Ada } \\
\text { perubahan }\end{array}$ \\
\hline & & $\begin{array}{l}\text { Kolaborasi } \\
\text { kelembagaan } \\
\text { dengan aktor } \\
\text { industri kreatif }\end{array}$ & 2 & 2 & $\begin{array}{l}\text { Tidak ada } \\
\text { perubahan }\end{array}$ & 2 & 2 & $\begin{array}{l}\text { Tidak ada } \\
\text { perubahan }\end{array}$ \\
\hline & Teknologi & $\begin{array}{l}\text { Teknologi untuk } \\
\text { pemanfaatan } \\
\text { bahan baku }\end{array}$ & 1 & 2 & $\begin{array}{c}\text { Ada } \\
\text { perubahan }\end{array}$ & 1 & 2 & $\begin{array}{c}\text { Ada } \\
\text { perubahan }\end{array}$ \\
\hline
\end{tabular}

Sub aspek (1) adalah modal SDM kreatif lokal dilihat dari sisi SDM yang mengandalkan inovasi dan kreativitas. Para pengusaha Batik di Kauman dan Pesindon melakukan inovasi setiap tahunnya, hal ini menunjukkan ada perubahan karena terdapat peningkatan jumlah SDM yang melakukan inovasi produk. Inovasi yang dilakukan yaitu berupa penciptaan ragam inovasi produk batik seperti Sarung Encim, sprei, mukena dan pembaharuan motif batik. SDM yang melakukan inovasi produk ini sudah sesuai dengan teori di mana menurut UNIDO (2007) kerajinan merupakan penciptaan yang salah satunya membutuhkan kreativitas pelaku usaha dan inovasi produk. Adanya perubahan ini berdampak pada tercapainya tujuan kota kreatif yaitu mendorong pemberdayaan SDM sehingga tercipta berbagai macam alternatif inovatif. Dengan demikian aspek pemeliharaan ekonomi kreatif dapat tercapai yaitu dengan adanya pelestarian kerajinan batik oleh SDM kreatif lokal.

Sub aspek (2) adalah dukungan wirausaha dan inovasi kreatif yang dilihat dari tiga sisi yaitu: (a) penyerapan tenaga kerja, di mana di Sentra Batik Kauman dan Pesindon telah menyerap tenaga kerja dari tahun 2014 sampai 2018 mengalami peningkatan jumlah tenaga kerja. Adanya penyerapan tenaga kerja industri batik ini tidak terlepas dari adanya dukungan wirausaha batik yang merekrut masyarakat sebagai tenaga kerja industri batik. Penyerapan tenaga kerja yang dilakukan oleh wirausaha batik ini dapat mendukung kota kreatif karena dapat tercapainya tujuan kota kreatif yaitu pemberdayaan SDM untuk mengatasi permasalahan ekonomi dengan membuka kesempatan pekerjaan atau penyerapan tenaga kerja. Adanya penyerapan tenaga kerja ini juga mendorong pemeliharaan ekonomi kreatif karena dapat tercapainya keberlanjutan modal sumber daya manusia dalam melestarikan kerajinan batik sehingga berdampak pada kestabilan ekonomi masyarakat. Selanjutnya adalah dari sisi (b) pertumbuhan jumlah perusahaan batik di mana jumlah unit usaha batik di Kauman dan Pesindon dari tahun 2014 s.d 2018 mengalami peningkatan. Jumlah unit usaha batik yang meningkat ini menunjukkan adanya perkembangan industri batik di Kauman dan Pesindon yang disebabkan karena ada peningkatan produksi batik yang kemudian berdampak pada meningkatnya jumlah penyerapan tenaga kerja. Departemen perdagangan RI (2008) menyebutkan industri kreatif memiliki karakteristik yaitu adanya pertumbuhan penyerapan tenaga kerja dan fluktuasi peningkatan jumlah perusahaan. Dari hal ini dapat menunjukkan adanya perubahan dan kesesuaian dengan teori yang dikaji sehingga dapat mendukung kota kreatif karena dapat tercapai tujuan kota kreatif yaitu untuk meningkatkan potensi ekonomi dari industri yang dipegang oleh aktor lokal yaitu pebisnis batik. Pertumbuhan jumlah unit usaha batik ini merupakan wadah untuk aktivitas proses kerajinan batik agar dapat berjalan sehingga dapat terpenuhinya aspek pemeliharaan ekonomi kreatif. Dari sisi (c) kolaborasi kelembagaan dengan berbagai aktor industri kreatif di mana selain lembaga keuangan sebagai lembaga 
intermediasi keuangan yang berperan meminjamkan modal kepada para pengusaha batik, konsep triple helix antara pebisnis, pemerintah dan masyarakat untuk pengembangan industri di Kauman dan Pesindon sudah berjalan. Sebagaimana disebutkan oleh Howkins (2001) bahwa karakteristik industri kreatif sebagai jantung ekonomi kreatif salah satunya yaitu adanya kolaborasi antara berbagai aktor yang berperan dalam industri kreatif baik akademisi, dunia usaha dan pemerintah. Peran dari akademisi juga ada, di Kauman yaitu pernah ada pelatihan motif batik dari aplikasi oleh Dosen Universitas Negeri Semarang. Fakta di lapangan terhadap isu awal dari sisi kelembagaan ini menunjukkan tidak ada perubahan karena sudah dilakukan sebelum penetapan kota kreatif sampai sekarang. Namun, hal ini tidak mendukung tujuan penetapan kota kreatif karena kelembagaan yang ada masih berjalan sendiri-sendiri. Peran yang terlihat adalah dari paguyuban kampung batik yang anggotanya juga ada dari pengusaha batik. Paguyuban ini untuk mewadahi kegiatan-kegiatan yang dapat mengembangkan promosi kerajinan batik di Kauman dan Pesindon.

Selanjutnya untuk sub aspek (3) yaitu teknologi yang dilihat dari sisi teknologi untuk pemanfaatan bahan baku menunjukkan ada perubahan. Proses pembuatan batik menggunakan teknologi sederhana, namun ada juga yang mengkombinasikan menggunakan teknologi modern sehingga menunjukkan adanya perubahan. UNIDO (2007) menyebutkan input dalam industri kerajinan selain kreativitas pelaku usaha dan inovasi produk, juga adanya bahan baku dan teknologi. Penggunaan teknologi modern ini hanya untuk membantu mendukung proses selanjutnya agar tidak membutuhkan waktu yang lama.

\subsection{PERUBAHAN ASPEK KOMUNITAS KREATIF}

Komunitas kreatif memiliki dua sub aspek yaitu keanekaragaman dan bakat yang bervariasi dan organisasi yang memungkinkan menjadi wadah kerjasama. Masing-masing sub aspek tersebut memiliki parameter yang menjadi tolak ukur dalam menilai ada dan tidak adanya perubahan.

Tabel 8. Perubahan Aspek Pemeliharaan Ekonomi Kreatif

\begin{tabular}{|c|c|c|c|c|c|c|c|c|}
\hline \multirow{2}{*}{ Aspek } & \multirow{2}{*}{ Sub Aspek } & \multirow{2}{*}{ Parameter } & \multicolumn{3}{|c|}{ Kauman } & \multicolumn{3}{|c|}{ Pesindon } \\
\hline & & & 2014 & 2018 & Hasil & 2014 & 2018 & Hasil \\
\hline \multirow[t]{2}{*}{$\begin{array}{l}\text { Komunitas } \\
\text { kreatif }\end{array}$} & $\begin{array}{l}\text { Keanekaragaman } \\
\text { dan bakat yang } \\
\text { bervariasi }\end{array}$ & $\begin{array}{l}\text { Ragam latar } \\
\text { belakang } \\
\text { masyarakat } \\
\text { sebagai } \\
\text { tenaga kerja } \\
\text { industri kreatif }\end{array}$ & 2 & 2 & $\begin{array}{l}\text { Tidak ada } \\
\text { perubahan }\end{array}$ & 2 & 2 & $\begin{array}{c}\text { Tidak ada } \\
\text { perubahan }\end{array}$ \\
\hline & $\begin{array}{l}\text { Organisasi yang } \\
\text { memungkinkan } \\
\text { menjadi wadah } \\
\text { kerjasama }\end{array}$ & $\begin{array}{l}\text { Organisasi } \\
\text { masyarakat } \\
\text { atau } \\
\text { paguyuban }\end{array}$ & 1 & 2 & $\begin{array}{c}\text { Ada } \\
\text { perubahan }\end{array}$ & 1 & 2 & $\begin{array}{c}\text { Ada } \\
\text { perubahan }\end{array}$ \\
\hline
\end{tabular}

Tabel 8 menunjukkan perubahan aspej pemeliharaan ekonomi kreatif di Sentra Batik Kauman dan Pesindoh. Di Sentra Batik Kauman dan Pesindon asal tenaga kerja sebagai industri kreatif menunjukkan tidak ada perubahan karena sudah ada pekerja dari dalam dan luar. Tidak hanya berasal dari dalam kawasan saja, tetapi juga membuka kesempatan dan keterbukaan masyarakat dari luar kawasan seperti dari Kabupaten Pekalongan dan Kabupaten Batang. Keragaman latar belakang tenaga kerja ini berdampak pada kesempatan para pendatang yang bukan berasal dari daerah Kauman dan Pesindon dalam menerima perbedaan sehingga hal ini juga dapat membantu perekonomian masyarakat luar kawasan. Adanya tenaga kerja dari luar ini juga berdampak pada proses pembuatan batik yang berjalan sebagaimana mestinya karena ada serangkaian proses yang di lakukan di luar kawasan seperti pewarnaan colet dan mopok sebagaimana dijelaskan menurut Landry (2006) bahwa keragaman yang tinggi dapat menjadi pertukaran ide untuk berinovasi. Keragaman latar belakang tenaga kerja ini tidak mendukung tujuan penetapan kota kreatif karena tidak ada kaitannya dengan teori karena inovasi produk yang dilakukan berasal dari pengusaha dan pengrajin kawasan Sentra Batik Kauman dan Pesindon itu sendiri, tidak dipengaruhi oleh asal dari tenaga kerja. Pembentukan aspek komunitas kreatif tidak memandang asal dan latar belakang pekerja atau masyarakat, melainkan orang yang ingin berkomitmen terhadap pelestarian budaya batik di Kota Pekalongan. 
Untuk organisasi masyarakat, di Sentra Batik Kauman dan Pesindon menunjukkan ada perubahan karena perkembangannya yang sudah mulai membuka kerjasama dengan Pekalongan Creative City Forum (PCCF) dan komunitas lain. Paguyuban Kampung Batik Kauman (PKBK) membentuk Omah Kreatif Kauman sebagai wadah kegiatan industri batik bagi para pengusaha batik di Kauman. Menurut Landry (2006), organisasi dapat menunjang kreativitas. Adanya organisasi juga dapat menjadi wadah melakukan kerjasama sehingga akan meningkatkan kemampuan untuk menciptakan inovasi. Florida (2005) juga menyebutkan komunitas kreatif mengutamakan keterlibatan masyarakat. Hal ini dapat terlihat dari adanya paguyuban yang berperan aktif bahkan diajak kerjasama oleh komunitas lain seperti PCCF dengan menggandeng komunitas fotografi Kota Pekalongan untuk mempromosikan wisata kreatif batik. Sementara itu, paguyuban di Pesindon juga pernah ada kegiatan yang menggandeng komunitas lettering Kota Pekalongan bersamaan dengan lkatan Pemuda Pesindon mengadakan kegiatan mural batik. Paguyuban Pesindon juga berperan membantu kegiatan yang diselenggarakan oleh Bank BRI di Sentra Batik Pesindon. Namun, peran dan kegiatan paguyuban saat ini kurang aktif sehingga hal ini berdampak ada program kegiatan yang belum terlaksana. Untuk kerjasama yang dilakukan antara Paguyuban Kauman dan Paguyuban Pesindon belum pernah ada misalnya untuk pengembangan industri kerajinan batik melalui event-event kreatif. Kondisi organisasi masyarakat berupa paguyuban ini dapat mendukung aspek komunitas kreatif yang melibatkan masyarakat untuk pengembangan industri batik di Kauman dan Pesindon sehingga dapat mendukung tujuan penetapan kota kreatif.

\subsection{PERUBAHAN ASPEK LINGKUNGAN KREATIF}

Lingkungan kreatif memiliki dua sub aspek yaitu ruang sebagai wadah berkreativitas dengan parameternya yaitu sarana untuk pusat pelatihan kerajinan dan sub variabel yang kedua yaitu infrastruktur yang relevan dengan kerajinan dengan parameternya yaitu berupa toko kerajinan atau showroom (Tabel 9).

Tabel 9. Perubahan Aspek Lingkungan Kreatif

\begin{tabular}{|c|c|c|c|c|c|c|c|c|}
\hline \multirow{2}{*}{ Aspek } & \multirow{2}{*}{ Sub Aspek } & \multirow{2}{*}{ Parameter } & \multicolumn{3}{|c|}{ Kauman } & \multicolumn{3}{|c|}{ Pesindon } \\
\hline & & & 2014 & 2018 & Hasil & 2014 & 2018 & Hasil \\
\hline \multirow[t]{2}{*}{$\begin{array}{l}\text { Komunitas } \\
\text { kreatif }\end{array}$} & $\begin{array}{l}\text { Ruang sebagai } \\
\text { wadah berkreativitas }\end{array}$ & $\begin{array}{l}\text { Sarana untuk } \\
\text { pusat } \\
\text { pelatihan }\end{array}$ & 1 & 2 & $\begin{array}{c}\text { Ada } \\
\text { perubahan }\end{array}$ & 1 & 2 & $\begin{array}{c}\text { Ada } \\
\text { perubahan }\end{array}$ \\
\hline & $\begin{array}{l}\text { Infrastruktur yang } \\
\text { relevan dengan } \\
\text { kerajinan }\end{array}$ & $\begin{array}{l}\text { Toko } \\
\text { kerajinan atau } \\
\text { showroom }\end{array}$ & 1 & 2 & $\begin{array}{c}\text { Ada } \\
\text { perubahan }\end{array}$ & 1 & 1 & $\begin{array}{l}\text { Tidak ada } \\
\text { perubahan }\end{array}$ \\
\hline
\end{tabular}

Di Sentra Batik Kauman dan Pesindon ada pusat pelatihan yang dikelola secara bersama. Kondisi ini menunjukkan ada perubahan karena yang sebelumnya masih berada di masing-masing unit usaha batik. Sarana sebagai pusat pelatihan selain di Museum Batik sebagai salah satu ikon pelestarian batik di Kota Pekalongan juga terdapat di Sentra Batik Kauman dan Pesindon. Baik di Kauman dan Pesindon sudah ada sarana pelatihan yang dikelola secara bersama yaitu berada di paguyuban kampung batik. Meskipun ada juga unit usaha batik yang menyediakan workshop khusus untuk mempelajari batik langsung dari pengrajin batik. Adanya pusat pelatihan pada satu tempat ini mempermudah akses bagi para pengunjung untuk langsung mempelajari batik lewat paguyuban sebagai suatu organisasi yang berperan dalam pengembangan industri batik di Kauman dan Pesindon. Adanya pusat pelatihan ini dapat mendukung tujuan penetapan kota kreatif karena sarana pelatihan batik menjadi salah satu indikator penilaian kota kreatif kerajinan. Hal ini dapat menciptakan lingkungan kreatif yang dapat menarik orang-orang untuk melakukan kreativitas.

Untuk showroom, di Sentra Batik Kauman saat ini sudah ada showroom yang dikelola bersama di Omah Kreatif Kauman. Jumlah UKM batik di Kauman yang menitipkan produknya melalui showroom ini berjumlah 15 UKM. Hal ini juga berdampak pada akses yang lebih mudah bagi para pengunjung untuk berbelanja dari para pelaku UKM batik sehingga tidak harus mengunjungi satu per satu. Namun, belum semua pelaku UKM memasarkan produknya lewat showroom bersama ini. Sementara itu, di Pesindon belum tersedia showroom bersama karena masih berada di masing-masing unit usaha batik. Hal ini dikarenakan rencana program dari paguyuban yang ingin menyediakan showroom bersama bagi para pelaku UKM batik di Pesindon belum terlaksana. Kondisi adanya sarana pelatihan dan showroom ini sesuai dengan teori di mana kriteria kota kreatif kerajinan menurut UNESCO (2004) salah satunya adalah adanya pusat pelatihan kerajinan dan infrastruktur yang relevan dengan kerajinan berupa toko kerajinan. Hal ini menunjukkan ada perubahan dalam mendukung Kota Kreatif 
Pekalongan. Namun untuk toko kerajinan di Sentra Batik Pesindon tidak mengalami perubahan. Adanya showroom bersama di Kauman ini mendukung tujuan kota kreatif sedangkan di Pesindon belum dapat mendukung kota kreatif.

\subsection{PERUBAHAN ASPEK PENYELENGGARAAN EVENT}

Penyelenggaraan event memiliki sub variabel yaitu event untuk promosi dengan parameternya berupa pameran atau festival. Di Kota Pekalongan sudah ada acara atau kegiatan yang berhubungan dengan kerajinan batik yang diadakan setiap tahun seperti Pekan Batik Nasional, Jetayu Car Free Night, Pekalongan Art Festival (Tabel 10). Event tersebut diikuti oleh peran aktif masyarakat termasuk para pelaku usaha batik.

Tabel 10. Perubahan Aspek Penyelenggaraan Event

\begin{tabular}{|c|c|c|c|c|c|c|c|c|}
\hline \multirow[b]{2}{*}{ Variabel } & \multirow[b]{2}{*}{ Sub Variabel } & \multirow{2}{*}{ Parameter } & \multicolumn{3}{|c|}{ Kauman } & \multicolumn{3}{|c|}{ Pesindon } \\
\hline & & & 2014 & 2018 & Hasil & 2014 & 2018 & Hasil \\
\hline $\begin{array}{l}\text { Penyelenggaraan } \\
\text { event }\end{array}$ & $\begin{array}{l}\text { Event untuk } \\
\text { promosi }\end{array}$ & $\begin{array}{l}\text { Program } \\
\text { penyelenggaraan } \\
\text { event berupa } \\
\text { festival atau } \\
\text { pameran }\end{array}$ & 1 & 2 & $\begin{array}{c}\text { Ada } \\
\text { perubahan }\end{array}$ & 1 & 2 & $\begin{array}{c}\text { Ada } \\
\text { perubahan }\end{array}$ \\
\hline
\end{tabular}

UNESCO (2004) menyebutkan kriteria kota kreatif kerajinan salah satunya adalah adanya upaya mempromosikan kerajinan dan kesenian rakyat berupa festival, pameran atau pasar. Selain event dalam skala kota, di Kauman dan Pesindon juga sudah ada festival yang diadakan atas inisiatif dari paguyuban. Di Kauman mulai diadakan pada tahun 2018 yaitu Kauman Art Festival, sedangkan di Pesindon sudah ada dari tahun 2017 yaitu Pesindon Fest. Dampak dari adanya penyelenggaraan event ini yaitu adanya pelibatan dan peran aktif masyarakat dalam memperkenalkan batik dan mempromosikan kampungnya sehingga dapat membuka tujuan wisata kreatif. Selain itu, dapat menjadi sarana hiburan bagi masyarakat dan membuat masyarakat lebih peka untuk terus melestarikan kebudayaan batik. Event-event yang diadakan di Sentra Batik Kauman dan Pesindon ini merupakan kegiatan atas inisiatif dari masyarakat sentra batik, bukan merupakan program yang diadakan oleh pemerintah setempat. Pemerintah hanya datang ketika masyarakat mengundang seperti misalnya untuk pembukaan acara atau peresmian suatu acara. Kegiatan atas inisiatif masyarakat ini yang kemudian dapat membuat Pemerintah Kota lebih bersemangat untuk mempromosikan dan memasarkan Batik Pekalongan. Adanya event festival ini menunjukkan ada perubahan dan mendukung penetapan Kota Kreatif Pekalongan serta sesuai dengan teori yang telah dibahas. Adanya kegiatan pameran ini yang kemudian dapat mendukung aspek promosi sehingga menarik wisatawan berkunjung.

\section{KESIMPULAN}

Perubahan pada Sentra Industri Batik di Kauman dan Pesindon dalam mendukung penetapan Kota Pekalongan sebagai kota kreatif kerajinan dapat dilihat melalui beberapa aspek yaitu pemeliharaan ekonomi kreatif, komunitas kreatif, lingkungan kreatif dan penyelenggaraan event. Masing-masing aspek memiliki sub aspek yang kemudian dijabarkan lagi ke dalam parameter untuk melihat kondisi perubahannya. Di Sentra Batik Kauman yang mengalami perubahan sehingga mendukung adanya penetapan Kota Kreatif Pekalongan yaitu pada modal SDM kreatif lokal, dukungan wirausaha dan inovasi kreatif yang dapat menyerap tenaga kerja, pertumbuhan jumlah perusahaan, teknologi, organisasi masyarakat, sarana sebagai pusat pelatihan kerajinan, infrastruktur yang relevan dengan kerajinan berupa showroom atau toko kerajinan dan program penyelenggaraan event berupa festival. Sementara itu di Sentra Batik Pesindon yang mengalami perubahan sehingga mendukung adanya penetapan Kota Kreatif Pekalongan yaitu pada modal SDM kreatif lokal, dukungan wirausaha dan inovasi kreatif yang dapat menyerap tenaga kerja, pertumbuhan jumlah perusahaan, teknologi, organisasi masyarakat, sarana sebagai pusat pelatihan kerajinan dan penyelenggaraan event berupa festival. Dari beberapa hal yang telah disebutkan dapat diketahui bahwa di Sentra Batik Kauman dan Pesindon sudah mendukung penetapan Kota Pekalongan sebagai kota kreatif kerajinan. 


\section{DAFTAR PUSTAKA}

Departemen Perdagangan RI. (2008). Rencana Pengembangan Ekonomi Kreatif Indonesia 2009-2015. Diakses dari https://www.slideshare.net/andrietrisaksono/buku-2-rencana-pengembangan-ekonomi-kreatif-indonesia-2009-2015

Evans, G., Foord, J., Gertler, M. S., Tesolin, L. \& Weinstock, S. (2006). Strategies for Creative Spaces and Cities: Lessons Learned. London Metropolitan University \& University of Toronto. Diakses dari http://www.web.net/ imagineatoronto/Creative_Cities_Lessons_Learned.pdf

Florida, R. (2005). Cities and Creative Class, City \& Community, 2(1), 3-19. DOI: 10.1111/1540-6040.00034

Howkins, J. (2001). The Creative Economy: How People Make Money from Ideas. London: Penguin Press.

Landry, C. \& Bianchini, F. (1995). The Creative City. London: Demos. Diakses dari https://www.demos.co.uk/files/thecreativecity.pdf Landry, C. (2006). The Art of City- Making, Journal Australian Planner, 43(4), 47. DOI: 10.1080/07293682.2006.9982528.

Peraturan Daerah Kota Pekalongan Nomor 4 Tahun 2016 tentang Rencana Pembangunan Jangka Menengah Kota Pekalongan Tahun 2016-2021.

Diakses

dari https://sikarep.pekalongankota.go.id/dok_regulasi/PERATURAN_DAERAH_KOTA_PEKALONGAN_NOMOR_4_TAHUN_2016_T ENTANG_RENCANA_PEMBANGUNAN_JANGKA_MENENGAH_DAERAH_KOTA_PEKALONGAN_TAHUN_2016-2021.pdf

Setiawan, G. (2004). Implementasi dalam Birokrasi Pembangunan. Jakarta: Cipta Dunia.

Soeprapto, S. (1985). Teknologi Tekstil. Jakarta: PT. Pardnya Paramita.

Trimargawati, N.E. (2008). Penerapan Hukum Hak Cipta Seni Batik Pekalongan sebagai Komoditas Internasional, Tesis. Semarang: Universitas Diponegoro. Diakses dari http://eprints.undip.ac.id/18449/1/NUR_ENDANG_TRIMARGAWATI.pdf

Undang-Undang Nomor 3 Tahun 2014 tentang Perindustrian. Diakses dari https://jdih.bsn.go.id/produk/detail/?id=11\&jns=2

UNDP-UNCTAD. (2008). Creative Economy Report, United Nations. Diakses dari https://unctad.org/en/Docs/ditc20082cer_en.pdf

UNESCO. (2004). The Creative Cities Network. United Nations. Diakses dari http://www.unesco.org/new/fileadmin/MULTIMEDIA/HQ/CLT/pdf/Creative_cities_brochure_en.pdf

UNIDO. (2007). Creative Industries and Micro \& Small Scale Enterprise Development. United Nations. Diakses dari https://www.unido.org/sites/default/files/2009-03/69264_creative_industries_0.pdf 